KS. ŁUKASZ KRUCKI* - GNIEZNO

\title{
RAPORT KS. MICHALA SOPOĆKI O STANIE KOŚCIOLA KATOLICKIEGO NA LITWIE I ZACHODNIEJ BIALORUSI PO ZAKOŃCZENIU II WOJNY ŚWIATOWEJ
}

Zakończenie II wojny światowej, jak i poczynione jeszcze przed nim ustalenia polityczne sprawiły, że granice państwa polskiego uległy zasadniczym przeobrażeniom. Demarkacja przeprowadzona na konferencji jałtańskiej przyczyniła się do tego, że Polska utraciła na rzecz ZSRR - Wileńszczyznę i zachodnią część Białorusi i Ukrainy ze Lwowem, a wiec tzw. Kresy Wschodnie. Uzyskała wprawdzie ziemie należące uprzednio do III Rzeszy, a które w nowej sytuacji politycznej nazwano Ziemiami Odzyskanymi (Dolny Śląsk, Śląsk Opolski, Pomorze Zachodnie i Mazury), ale była to zamiana, która burzyła przedwojenną strukturę państwa polskiego. Negatywnie wpłynęła ona również na stosunki kościelne. Niwelowała bowiem zreorganizowaną $\mathrm{w}$ okresie międzywojennym strukturę diecezjalną. Poza nowymi granicami Polski znalazły się stolice biskupie w Wilnie, Pińsku, Łucku i Lwowie ${ }^{1}$. Na ziemiach pozyskanych trzeba było natomiast tworzyć nową strukturę diecezjalną, co w rzeczywistości rodzącego się państwa komunistycznego stanowiło zadanie niełatwe. Wiedzieli o tym nie tylko hierarchowie Kościoła katolickiego w Polsce, zdawała sobie z tego sprawę również Stolica Apostolska, stąd też 8 VII 1945 r. udzieliła ona prymasowi Augustowi Hlondowi specjalnych uprawnień (in tutto il territorio polacco), które odnosiły się do całego terytorium ziem polskich, zarówno tego sprzed $1939 \mathrm{r}$., jak i po $1945 \mathrm{roku}^{2}$. Ich zasadniczym celem było ułatwienie prymasowi Hlondowi wprowadzania nowego ładu kościelnego na Ziemiach Zachodnich, lecz salezjański kardynał nie omieszkał również skorzystać z nich, aby zapoznać się ze stanem Kościoła i położenia katolików pod panowaniem sowieckim. Zaangażowanie to nie osłabło również po 4 III 1946

\footnotetext{
*Ks. Łukasz Krucki - dr historii Kościoła, pracownik merytoryczny Archiwum Archidiecezjalnego w Gnieźnie.

${ }^{1}$ Z. Zieliński, Dyplomacja polska wobec Watykanu w latach 1945-1989, w: Historia dyplomacji polskiej, t. 6, red. W. Materski, W. Michowicz, Warszawa 2010, s. 896.

${ }^{2}$ J. Pietrzak, Działalność kard. Augusta Hlonda jako wysłannika na Ziemiach Odzyskanych w 1945 r., „Nasza Przeszłość”, 42 (1974) s. 197-198.
} 
r., gdy anulowane zostały jego dotychczasowe pełnomocnictwa, a w ich miejsce nadane inne, określone jako „szerokie”, choć brzmiące równie enigmatycznie jak poprzednie: pro territorio polono. Zasadnicza różnica $\mathrm{w}$ odniesieniu do poprzednich polegała jednak na tym, iż uzyskane uprawnienia musiał dzielić z kardynałem Adamem Sapiehą. Ustalono wówczas, iż hierarcha krakowski swoją władzą obejmie prowincje krakowską i lwowską, podczas gdy pozostałe terytorium Polski podlegać będzie jurysdykcji prymasa Polski ${ }^{3}$. W strefie wpływów tego ostatniego znalazły się więc zarówno Ziemie Odzyskane, jak i znaczna część przedwojennych Kresów Wschodnich - Wileńszczyzna i Zachodnia Białoruśs

\section{Sytuacja Kościoła katolickiego na Litwie i Zachodniej Białorusi}

Kościół katolicki na Litwie ${ }^{5}$ Zachodniej Białorusi w okresie okupacji niemieckiej, a następnie sowieckiej, doznał niespotykanych wcześniej krzywd osobowych i strat $\mathrm{w}$ stanie posiadania, zarówno na płaszczyźnie budynków sakralnych, jak i ich wyposażenia liturgicznego. Podczas okupacji hitlerowskiej (19411944) interesujące nas tereny weszły w skład Generalnego Okręgu Litwa, który swoim zasięgiem obejmował całą Litwę Kowieńską oraz część Wileńszczyzny z Wilnem. Generalnym komisarzem tego okręgu został dr Adrian von Renteln, który rezydował w Kownie. Część białoruską natomiast włączono do Generalnego Okręgu Białoruś, na czele którego stanął Wilhelm Kube, a od 1943 r. Curt von Gettberg ${ }^{6}$. Zarazem von Renteln, jak i von Gettberg prowadzili wyjątkowo okrutną politykę wobec miejscowej ludności. Odium prześladowań spadł głównie na miejscowych Żydów, choć eksterminacja nie ominęła Polaków, Litwinów i Białorusinów. Ludność $\mathrm{z}$ okupowanych terenów prześladowano nie tylko ze względu na pochodzenie etniczne, ale także z powodu wyznawanej wiary. Katolicy należeli do tej grupy konfesyjnej, która w sposób szczególny została poddana represjom. Ogniskowały się one nie tylko na utrudnianiu prowadzenia duszpasterstwa, ale przede wszystkim na eliminacji duchowieństwa - kara śmierci bądź zsyłka do obozów koncentracyjnych ${ }^{7}$.

Choć 1944 r. zakończył się dla tych ziem okres okupacji niemieckiej, to jednak rozpoczynał się nowy - tym razem sowieckiej. Jej przedsmak dał się odczuć mieszkańcom Zachodniej Białorusi po 17 IX 1939 r., a na Litwinom w latach 1940-1941. Wyparcie Niemców otwierało jednak zupełnie nowy okres w dziejach Kresów Wschodnich. Sowieci legitymizując swoją władzę, rozpoczęli od

${ }^{3}$ Tenże, Petnia prymasostwa. Ostatnie lata prymasa Polski kardynała Augusta Hlonda 1945-1948 , t. 1, Poznań 2009, s. 45.

${ }^{4}$ Tamże, t. 2, s. 543-545.

${ }^{5}$ Ks. Michał Sopoćko mówiąc o Kościele katolickim na Litwie ma na myśli zarówno przedwojenną archidiecezję wileńską, jak i diecezje leżące przed 1940 r. w Republice Litewskiej (Litwie Kowieńskiej). Zob. Raport.

${ }^{6}$ T. Krahel, Archidiecezja wileńska, w: Życie religijne w Polsce pod okupacja 1939-1945. Metropolie wileńska i lwowska, zakony, red. Z. Zieliński, Katowice 1992, s. 15-16.

${ }^{7}$ Tamże, s. 22-28. 
prześladowania Kościoła katolickiego. Proces ten nasilił się po 1945 r., gdy tereny te oficjalnie włączono do ZSRR (Litewska Socjalistyczna Republika Radziecka i Białoruska Socjalistyczna Republika Radziecka). Jego apogeum przypadł jednak na lata 1945-1947. Wówczas to rozpoczęto systematyczne aresztowania duchownych, w tym i biskupów (dwóch - T. Matulionisa z Koszedar i V. Boriseviciusa z Telesz - skazano na karę śmierci). Ponadto wytaczano księżom sfingowane procesy, na których ferowano wyroki wieloletniego więzienia, pracy w łagrach, a nawet kary śmierci. Zamknięto seminaria duchowne, pozostawiając tylko jedno - w Kownie. Oficjalnie miało ono przygotowywać kadry duchowieństwa, lecz wśród alumnów umieszczano agentów, którzy przyjmowali nawet święcenia kapłańskie, a przez to wchodzili w szeregi kapłańskie ${ }^{8}$.

Urzędy diecezjalne, parafie oraz duchowieństwo pozbawione zostały przysługujących im dochodów, pozyskiwanych dotychczas z beneficjów, te bowiem znacjonalizowano. Ciężar finansowania działalności Kościoła spoczął na barkach wiernych, którzy za publiczne przyznanie się do katolicyzmu mogli spodziewać się represji, jak choćby zwolnienia z pracy, czy wytoczenia procesu. Jednocześnie rozpoczęto systematyczną ateizację społeczeństwa, która zakładała: wprowadzenie nadzoru nad sprawowanym kultem przez specjalne komitety, ograniczenie (a właściwie wyrugowanie) duszpasterstwa prowadzonego $\mathrm{w}$ szpitalach $\mathrm{i}$ innych ośrodkach odseparowania wiernych od kościoła, czy też utrudnianie młodzieży uczestnictwa w katechizacji9.

Doskwierający brak księży, prześladowania wiernych i przymusowa sowietyzacja połączona $\mathrm{z}$ ateizacją sprawiły, iż na Litwie i Zachodniej Białorusi nie tylko znacznie podupadła świadomość religijna, ale również uległa zachwianiu moralność autochtonów, w znacznej mierze pod wpływem przybyszów ze Wschodu. Pijaństwo, rozboje, gwałty i rozwody stały się plagą tych terenów w pierwszych latach po zakończeniu wojny ${ }^{10}$.

\section{Okoliczności powstania raportu}

Może zrodzić się pytanie: ile prymas Hlond wiedział o skali prześladowań Kościoła i katolików na Wschodzie i skąd czerpał o nich informacje? Choć odpowiedzi może być kilka, to najodpowiedniejszą będzie prawdopodobnie ta, że od powracających do Polski repatriantów. Przesiedleńcy zza Buga przywozili ze sobą wieści o zachodzących przeobrażeniach, które dotykały szczególnie Polaków, zwłaszcza zaś katolików. Informowali o likwidowanych parafiach i zamykanych kościołach, a także o losie duchownych, doświadczanych przez system

${ }^{8}$ B. Kumor, Historia Kościoła, cz. 8: Czasy wspótczesne 1914-1992, Lublin 1996, s. 215-216.

${ }^{9}$ B. Cywiński, Ogniem próbowane. Z dziejów najnowszych Kościoła katolickiego w Europie Środkowo-Wschodniej, t. 2: „...i was prześladować będą”, Warszawa 1994, s. 146-147, 153-154.

${ }^{10} \mathrm{~J}$. Wołkonowski, Wspótczesna sytuacja polskiej mniejszości na Litwie: płaszczyzna konfliktu i wspótpracy z instytucjami państwa litewskiego i społeczeństwem obywatelskim, w: Życie społeczne Polaków na Wschodzie. Wybrane zagadnienia, red. A. Bobryk, Siedlce 2007, s. 61-62. 
komunistyczny ${ }^{11}$. Jednym z takich przybyszów był ks. Michał Sopoćko ${ }^{12}$, profesor wileńskiego seminarium duchownego. Po przymusowym opuszczeniu Wilna, przybył on do Warszawy 9 VIII 1947 r. Prymas dowiedziawszy się o przybyciu Sopoćki do stolicy, poprosił go o sporządzenie specjalnego raportu. Pragnął, aby wileński profesor zawarł w nim spostrzeżenia dotyczące sytuacji Kościoła na Litwie i Zachodniej Białorusi od zakończenia wojny aż do czasu jego przybycia do Polski. Kapłan-repatriant przystąpił do przygotowania odpowiedniego pisma jeszcze w sierpniu 1947 r. Ukończył je 27 VIII tr., a dwa dni później - 29 VIII trafiło ono do Sekretariatu Prymasa Polski.

Ksiądz Sopoćko w swoim raporcie nie tylko wskazał na stan Kościoła i jego wiernych na Kresach Wschodnich, na niedostatek duchownych na tych terenach, ale również zawarł pewne wskazówki, które zrealizowane mogłyby ulżyć jego położeniu. Były to trzy sugestie: 1) zorganizowanie specjalnego „Dzieła powołań spóźnionych", którego konstytutywnym zadaniem powinno być przygotowanie kandydatów do seminariów, przekraczających wiekiem okres szkolny; 2) wykształcenie katechetów i katechetek do prac misyjnych na Wschodzie; 3) urządzenie odpowiednich kursów katechetycznych dla kandydatów do prac wśród ludu i inteligencji ${ }^{13}$. Prymas zapoznawszy się z przygotowanym sprawozdaniem i jego końcowymi wnioskami, mimo chęci, praktycznie nic nie mógł w tej materii uczynić ${ }^{14}$.

\section{Cele i zasady wydawnictwa źródłowego}

Zasadniczym motywem skłaniającym do wydania niniejszego Raportu była chęć wypełnienia, przynajmniej w niewielkim stopniu, luki badawczej nad stanem Kościoła w ZSSR. Relacja przygotowana przez ks. Michała Sopoćkę przynosi $\mathrm{w}$ tej dziedzinie wiele ciekawych i nader ważnych informacji, które dotykają relacji społecznych, narodowych, konfesyjnych i duszpasterskich na Wileńszczyźnie oraz Zachodniej Białorusi lat 1945-1947, a przez to stanowi ważny przyczynek do poznania dziejów Kościoła katolickiego na tych terenach.

Za podstawę niniejszego wydania posłużył czterostronicowy maszynopis Raportu przechowywany w Archiwum Archidiecezjalnym w Gnieźnie ${ }^{15}$. Jest on częścią powojennych Akt Prymasa Polski (aktualnie opracowywanych), stąd też

${ }^{11}$ Pietrzak, Petnia prymasostwa, t. 2, s. 545.

${ }^{12}$ Michał Sopoćko (1888-1975), duchowny katolicki, ojciec duchowny seminarium w Wilnie (1927-1932), wykładowca teologii pastoralnej na Wydziale Teologicznym Uniwersytetu Stefana Batorego w Wilnie (1928-1940) i w seminariach duchownych w Wilnie (1928-1940; 1944/45) i Białymstoku (1977-1962). Oprócz pracy naukowo-wychowawczej i publicystycznej prowadził działalność duszpasterską. Zasłynął jako spowiednik św. siostry Faustyny Kowalskiej i promotor kultu Miłosierdzia Bożego. Beatyfikowany w 2008 r. Zob. E. Ozorkowski, Stuga Boży ks. Michał Sopoćko, „L'Osservatore Romano” 9 (2008), s. 59-60.

${ }^{13}$ Raport.

${ }^{14}$ Pietrzak, Petnia prymasostwa, t. 2, s. 548.

${ }^{15}$ Archiwum Archidiecezjalne w Gnieźnie, Akta Prymasa Polski I, b. sygn., Korespondencja z duchowieństwem 1945-1948, k. 177-180. 
przygotowując jego kopię wydawniczą, zastosowano wskazówki podane przez odpowiednią dla tego okresu historycznego instrukcję wydawniczą ${ }^{16}$.

\section{$* * * * *$ \\ DO JEGO EMINENCJI KARDYNAŁA AUGUSTA HLONDA, PRYMASA POLSKI}

Ks. Michała Sopoćki z archidiecezji wileńskiej

przybyłego z Wilna 9 sierpnia $1947 \mathrm{r}$.

\section{Raport}

Stosownie do ustnego polecenia ${ }^{a-W A S Z E J ~ E M I N E N C J I-a ~ m a m ~ z a s z c z y t ~}$ przedłożyć niniejszy raport o stanie Kościoła na Litwie Sowieckiej i Białorusi, skąd obecnie przybywam.

Tak zwana Litwa Sowiecka obejmuje 5 diecezji Litwy przedwojennej i część archidiecezji wileńskiej. Na całym terenie zamieszkiwało około trzech milionów wiernych, około 2 tysięcy kapłanów i 10 biskupów. Obecnie pozostał tylko jeden biskup, J. E. Połtarokas ${ }^{17}$ w Poniewieżu. Wszyscy inni zostali wywiezieni, aresztowani a biskup telszewski J. E. Borysewicz ${ }^{18}$ - skazany na śmierć (są pogłoski, że jeszcze żyje). Ostatnio w roku bieżącym zmarł biskup Karaś ${ }^{19}{ }^{2}$ Mariampolu ${ }^{20}$, a 12 czerwca został osadzony w więzieniu śledczym J. E. Rejnis ${ }^{21}$ - sufragan wileński. Aresztowano również lub się ukrywa prawie połowa kapłanów.

$\mathrm{Na}$ całą Litwę pozostaje jedno seminarium w Kownie z ograniczoną do 150 ilością alumnów, których ustawicznie nękają rewizjami i badaniami ze zmusza-

a-a Wyróżnienia $w$ tekście wielkimi literami, to i następne, zostały dokonane przez autora Raportu $i$ tak je pozostawiono.

${ }^{16}$ I. Ihnatowicz, Projekt instrukcji wydawniczej dla źródet historycznych XIX $i$ początku XX wieku, „Studia Źródłoznawcze”, 12 (1965/66) s. 99-123.

${ }^{17}$ Kaziemiras Paltarokas (1875-1958), duchowny katolicki, biskup poniewieski (1926-1957), administrator apostolski w Wilnie (1949-1957). Ofiara represji stalinowskich. 8 XII 1957 r. zrezygnował z zarządu powierzonych mu diecezji. Zmarł w Poniewieżu 3 I 1958 r.

18 Vincentas Borisevicius (1887-1946), duchowny katolicki, biskup pomocniczy telszewski (1940-1944), a następnie ordynariusz tej diecezji (1944-1946). Ofiara represji stalinowskich. Skazany na śmierć. Wyrok wykonano 18 XI 1946 r.

19 Antoni Karaś (Karosas) (1856-1947), duchowny katolicki, biskup pomocniczy łucko-żytomierskim (1906-1910), ordynariusz augustowski (1910-1926), ordynariusz wiłkowyski (19261947). Ofiara represji stalinowskich. Zmarł 7 VII 1947 r.

20 Mariampol - obecnie miasto w południowej części Litwy, nad rzeką Szeszupą, stolica województwa.

${ }^{21}$ Mecislovas Reinys (1884-1953), duchowny katolicki, biskup koadiutor wiłkowyski (19261940), arcybiskup koadiutor wileński (1941-53). W 1947 r. skazany na 10 lat więzienia, zmarł w trakcie odsiadywania wyroku we Włodzimierzu 8 XI 1953 r. 
niem do szpiegostwa i współpracy z NKWD ${ }^{22}$ i $\mathrm{NKGB}^{23}$, a opornych lub niewiernych złożonym przyrzeczeniom aresztują i wywożą na Wschód do przymusowych robót. Ostatnio aresztowano i wywieziono dwu alumnów archidiecezji wileńskiej, uczących się w kowieńskim seminarium duchownym.

Duchowieństwo i seminarium utrzymuje się tylko z ofiar wiernych, gdyż beneficja zostały znacjonalizowane. Pozostawiono tylko przy parafialnych kościołach po 3 ha, za które trzeba płacić dość wysokie podatki. Podatkami są obłożone wszystkie (z wyjątkiem zakonnych) kościoły zależnie od objętości. Na kościele np. katedralnym w Wilnie ciążył podatek 3 tysięcy rubli za lata 1945-1946, nieco potem zmniejszony wskutek zabiegów kustosza. Nadto na każdym duchownym ciężył podatek osobisty, dowolnie wymierzany przez władze podatkowe i często niepomiernie wysoki, wprost niemożliwy do uiszczenia. Za niezapłacenie podatków grozi sąd, konfiskata mienia i więzienie. Dotychczas nie słyszałem o stosowaniu tych gróźb do duchowieństwa, które w miarę możliwości z podatków choć częściowo się uiszcza. Ostatnio kilku kapłanów w Wilnie otrzymało wezwanie do sądu i zaoczny wyrok na grzywny, od którego apelowali do wyższej instancji.

Mimo oficjalnie głoszonej swobody wyznania istnieje prześladowanie wiernych za praktyki religijne, szczególnie w stosunku do wojskowych i urzędników, wskutek czego słabsi w wierze powoli obojętnieją i te praktyki zaniedbują, a gorliwsi i mocniejsi - kryją się, udając się do nieznanych miejscowości w celu przystąpienia do sakramentów św. Raz po raz przybywają do Wilna nowożeńcy z całej Litwy, by w ukryciu zawrzeć związek małżeński. Wobec tego stale pogarsza się stan religijno-moralny: małżeństwa niekościelne są na porządku dziennym, dzieci z takich małżeństw stanowią coraz większy odsetek przynoszonych do chrztu (po miastach do 30\%), a wielu rodziców - (szczególnie w małżeństwach zawieranych z przybyszami ze Wschodu) już się o ten sakrament wcale nie troszczy. Jest sporo i mężnych wyznawców Chrystusa, szczególnie wśród młodzieży akademickiej, która manifestacyjnie wypełnia swój kościół, przystępuje do sakramentów, powodując tym zgrzytanie zębów swoich oficjalnych wychowawców.

Nauczanie młodzieży religii odbywało się po kościołach w zakrystiach lub kaplicach według skróconego programu, gdyż młodzież z rozmaitych powodów regularnie nie uczęszczała (z małym wyjątkiem). Na początku ubiegłego roku szkolnego naczelnicy kultu powiadomili, by w żadnym wypadku nauczanie religii nie odbywało się w dnie powszednie w związku ze szkołą, a tylko w dnie świąteczne i niedzielne w związku z nabożeństwem, na które znowu władze szkolne uniemożliwiały pójście, urządzając w tym czasie jakieś nadprogramowe pogadanki, lub prowadząc młodzież do kina. Wówczas wyłoniła się potrzeba mszy popołudniowych o godz. 18 i 20 wieczorem, na które przybywało sporo młodzieży (w Wilnie) i odbywała się katechizacja. Przygotowanie dzieci do pierwszej spo-

${ }^{22}$ NKWD - Ludowy Komisariat Spraw Wewnętrznych. Centralny organ państwowy w ZSRR zajmujący się działalnością w zakresie bezpieczeństwa wewnętrznego, wywiadu, jak i kontrwywiadu. W 1946 r. przemianowany na Ministerstwo Spraw Wewnętrznych ZSRR.

${ }^{23}$ NKGB - Ludowy Komisariat Bezpieczeństwa Państwowego. Urząd ministerialny w ZSRR realizujący zadania przynależne do wywiadu i kontrwywiadu. W 1946 przekształcony w Ministerstwo Bezpieczeństwa Państwowego ZSRR. 
wiedzi i Komunii św. odbywało się również po kościołach w miesiącach letnich i wiosennych. W roku bieżącym na wiosnę w niektórych okręgach to przygotowanie zostało zakazane pod surowymi karami; ponoć przygotować mogą tylko rodzice swe dzieci w wieku, w którym same o praktykach religijnych zadecydują.

Obsługiwanie chorych w szpitalach zostało ostatnio uniemożliwione zarządzeniem, by ksiądz w żadnym wypadku nie miał do szpitala wstępu, ani nie był wzywany przez służbę, a tylko mógł przyjść na prośbę samego chorego (w jaki sposób!?), albo jego rodziny, której również wstęp jest dozwolony tylko raz na tydzień. Wobec tego chorzy w szpitalu unikają albo pozostają bez posług duchownych. Pod względem higienicznym szpitale te stoją niżej krytyki. Ilość szpitali chorób skórnych coraz bardziej się mnoży, a chorzy się w nich nie mieszczą. Brak lekarstw uniemożliwia leczenie, co również wpływa bardzo ujemnie na stan religijno-moralny mieszkańców. Wśród nieuleczalnie chorych mnożą się wypadki samobójstwa.

Niedostateczność zarobków i zupełny brak ich zmusza wielu do szukania środków do życia w kradzieży i rabunkach, które się dokonują w biały dzień na porządku dziennym. Sprawcami ich są przeważnie przybysze ze Wschodu, szczególnie tak zwani „biezpryzornyje”, młodzieńcy, których pełno po rynkach w miastach, miasteczkach i na wsi, oddających się nadto rozpuście, gwałtom i pijaństwu. Właśnie pijaństwo stało się bodaj największą plagą, która demoralizuje starsze i młodsze pokolenie, zadając śmiertelne rany życiu religijnemu. Piją ohydny samogon; raczą się nim małe dzieci, a nawet rodzice wlewają go do ust niemowlętom. Współczesne hasła wywrotowe znajdują adeptów przeważnie wśród alkoholików, którzy za wódkę sprzedają swoich sąsiadów, swoje religijne przekonanie i swoje sumienie. Ofiarą napadów rabunkowych bardzo często są plebanie.

$\mathrm{Na}$ osłabienie życia religijnego na Litwie mają duży wpływ narodowościowe antagonizmy, które dzisiaj nieco się zmniejszyły, ale żyją w smutnych wspomnieniach i faktach. Dotychczas na Litwie nigdzie nie ma (z wyjątkiem Wilna i okolic) nabożeństwa dodatkowego $\mathrm{w}$ języku polskim, chociaż Polacy stanowią duży odsetek mieszkańców, wskutek czego niektórzy Polacy przestali uczęszczać do kościoła i przystępować do sakramentów świętych. Wielokrotnie sam spowiadałem takich, którzy po dwadzieścia lat nie byli u spowiedzi jedynie dlatego, że nie chciano ich spowiadać po polsku. W diecezji np. koszedarskiej ${ }^{24}$ (która przed wojną światową stanowiła część wileńskiej) znam dobrze parafię janiską (Janiŝki²5), gdzie w r. 1941 zastępowałem przez parę miesięcy miejscowego ks. proboszcza. Zgodnie $\mathrm{z}$ rozporządzeniem ówczesnego administratora apostolskiego było tam przed sumą kazanie litewskie, a po sumie polskie. Otóż na kazanie litewskie absolutnie nikt nie przychodził, gdy na kazaniu polskim kościół był przepełniony. Dzisiaj w tym kościele nie ma ani kazania, ani żadnego nabożeństwa dodatkowego w języku polskim, chociaż ludność rozmawia po polsku i modli się w swoim ojczystym języku, jak o tym sam przekonałem się 29 czerwca roku bieżącego w Kalwarii Wileńskiej, gdzie spotkałem z Janiszek pielgrzymkę, śpiewającą wy-

\footnotetext{
${ }^{24}$ Diecezja koszedarska - rzymskokatolicka diecezja na Litwie, erygowana 4 IV 1926 r.

${ }^{25}$ Janiškiai - obecnie wieś na Litwie, w rejonie malackim.
} 
łącznie po polsku. Na pytanie moje, dlaczego przyszli bez księdza, usłyszałem odpowiedź: „Nie mamy dziś księdza, gdyż w roku bieżącym już dwóch kolejno proboszczów w naszej parafii aresztowano a trzeci jeszcze nie przybył. Teraz korzystamy z okazji, że możemy śpiewać po polsku, gdyż księża nam zabraniają". To samo dzieje się w wielu innych parafiach na wsi i w miastach. W Kownie np. nie ma również ani kazania ani żadnego nabożeństwa dodatkowego w języku polskim, chociaż tam jest dużo Polaków. Zwiedzając to miasto stawiałem pytania po litewsku i prawie zawsze otrzymywałem odpowiedź po polsku.

Na tak zwanej Białorusi Zachodniejej, obejmującej część archidiecezji wileńskiej i diecezji pińskiej jest pod pewnym względem jeszcze gorzej: najbardziej odczuwa się brak duchowieństwa, gdyż w niektórych dekanatach pozostało tylko paru księży, szczególnie w diecezji pińskiej. Jakkolwiek są tam delegaci metropolity, to jednak wszyscy odczuwają brak biskupa, i wskutek czego brak jednolitości w ustosunkowaniu do władz cywilnych. W roku bieżącym na wiosnę władze te zarządziły rejestrację kościołów, która polegała na tym, że przy każdym kościele ma być komitet z 20 osób, który rejestruje kościół i cały inwentarz, zwraca się do władz cywilnych z prośbą o pozwolenie na korzystanie z niego i staje się gospodarzem, od którego proboszcz będzie całkowicie zależny. Zatwierdzony przez władze cywilne przewodniczący komitetu może pewnych członków usunąć, a przyjmować innych. Na skutek uchwały takiego komitetu kościół może nie tylko służyć celom kultu. Takiemu żądaniu przeciwstawił się arcybiskup Rejnis (i chyba za to został aresztowany), a za nim inni rządcy diecezji na Litwie. Natomiast na Białorusi nie było jednolitości pod tym względem i wielu proboszczów musiało się zgodzić na taką rejestrację. Inni znowu, powołując się na stanowisko arcybiskupa Rejnisa zajęli stanowisko wyczekujące.

Wśród ludności na Białorusi duch i nastrój jest bodaj lepszy, niż na Litwie, chociaż ucisk jest większy; kontyngenty są bardzo wielkie, po ich oddaniu ludność pozostaje prawie przy niczym. Ze wschodniej Białorusi i Ukrainy przybywa wciąż wielka ilość głodujących biedaków, którzy się dopuszczają kradzieży i rabunku. Mimo to ludność jest dobrej myśli i żyje nadzieją na lepszą przyszłość. Pozostali na stanowiskach księżą obsługują po kilka parafii, zjeżdżają się na odpusty ku wielkiemu zbudowaniu wiernych, urządzają rekolekcje, na które przybywają nieraz zatwardziali grzesznicy. Księża dziekani organizują również rekolekcje kapłańskie z okazji 40-godzinnego nabożeństwa; zbiera się 10-12 kapłanów, którzy po paru godzinach pracy w kościele oddają się następnie ćwiczeniom duchownym. Z okazji rekolekcji kapłańskich byłem w kilku dekanatach na Białorusi i wszędzie budowałem się nastrojem, zapałem i pracą konfratrów, mimo iż na każdym kroku grozi niebezpieczeństwo. Ostatnio (w lipcu) na Białorusi aresztowano

${ }^{26}$ Zachodnia Białoruś - umowna nazwa ziem na Kresach Wschodnich II Rzeczpospolitej zajętych przez ZSRR po 17 IX 1939 r., które wcześniej graniczyły z Białoruską Socjalistyczną Republiką Radziecką. 
4 kapłanów, jeden z nich (ks. Pupin ${ }^{27}$ ) obsługiwał pięć kościołów (w Chożowie ${ }^{28}$, Oborku $^{29}$, Horodziłowie ${ }^{30}$, Gródku$^{31}$ i Chouchle ${ }^{32}$ ) oraz kaplicę w Jarszewiczach ${ }^{33}$ obwodu mołodoczańskiego ${ }^{34}$.

Na prośbę wiernych (Rosjan oraz zrusyfikowanych Polaków i Litwinów) przybyłych z Rosji i nowo nawróconych oraz na skutek polecenia arcybiskupa Rejnisa od 17 marca 1946 r. aż do wyjazdu z Wilna (29 VII 1947 r.) w kościele Świętej Trójcy w Wilnie odprawiałem w niedziele i dni świąteczne nabożeństwo z kazaniem, śpiewem i dodatkowymi modlitwami w języku rosyjskim. Zainteresowanie było duże i nawróceń przy tej okazji sporo. Atoli w ostatnich miesiącach ilość uczestników nieco się zmniejszyła wobec obawy przed NKWD, które zaczęło przysyłać swoich wywiadowców - nieraz z aparatami fotograficznymi, by się przekonać, kto na te nabożeństwa uczęszcza. Przekonałem się przy tej okazji, że i obrządek łaciński nie odstręcza Rosjan, jeżeli uwzględnić ich język w dodatkowym nabożeństwie, przeciwnie, osoby inteligentne nawet przyciąga. Boją się oni tylko swoich władz, które faworyzują prawosławie, a wrogo się ustosunkowują do katolicyzmu. Pewien np. wyższej rangi wojskowy nie chciał przy ślubie złożyć swojego podpisu z obawy, że będzie wykryte jego przyjęcie katolicyzmu. Na uwagę, że to zostanie w tajemnicy, odpowiedział, że na pewno wszystkie akty kościelne wkrótce znajdą się w NKWD. ZSSR ${ }^{35}$ szykuje się do wielkiej rozprawy z Kościołem katolickim, który jeden tylko stanowi poważne dla nich niebezpieczeństwo, gdyż prawosławie już prawie nie istnieje, albowiem wszyscy biskupi prawosławni na czele z patriarchą, jak również większość kleru niższego pozostają na usługach NKWD. Wobec tego pozostaje tylko Kościół katolicki najbardziej przysposobiony do walki, na który ZSSR nigdy się nie zgodzi. Potęgę Kościoła katolickiego oni doskonale rozumieją i w organizacji go naśladują; mają swego nieomylnego papieża, którego komentowaniem mów wszyscy są zajęci, mają sprężystą administrację, doskonały wywiad, mają nawet spowiedź każdego członka przed zarządem, ekskomunikę itp. ZSSR zgodzi się na każdą inną religię tylko nigdy na religię katolicką, do walnej bitwy, z którą szykuje się z większym przygotowaniem, niż do walki z jakimkolwiek innym nieprzyjacielem! A gdy oświadczyłem, że jesteśmy przygotowani na wszystko i wynik tej walki jest dla nas pewny, odpowiedział, że oni się właśnie i boją tego ostatecznego wyniku.

${ }^{27}$ Piotr Pupin (1912-1979), duchowny katolicki. W latach 1940-1955 aresztowany i represjonowany w sowieckich łagrach. Od 1955 r. proboszcz w Rubieżewiczach na Białorusi. Zmarł 13 VIII $1979 \mathrm{r}$.

${ }^{28}$ Chożów - obecnie wieś na Białorusi, w rejonie mołodeczańskim, w obwodzie mińskim.

${ }^{29}$ Oborek - obecnie wieś na Białorusi, w rejonie mołodeczańskim, w obwodzie mińskim.

${ }^{30}$ Horodziłów - obecnie wieś na Białorusi, w rejonie mołodeczańskim, w obwodzie mińskim.

${ }^{31}$ Gródku - obecnie wieś na Białorusi, w rejonie mołodeczańskim, w obwodzie mińskim.

${ }^{32}$ Chołchło - obecnie wieś na Białorusi, w rejonie mołodeczańskim, w obwodzie mińskim.

${ }^{33}$ Jarszewicze - obecnie wieś na Białorusi, w obwodzie mińskim.

${ }^{34}$ Obwód mołodoczański - jednostka administracyjna w Białoruskiej Socjalistycznej Republice Radzieckiej, istniejąca w latach 1944-1960 i obejmująca tereny dawnego obwodu wilejskiego.

${ }^{35}$ ZSSR - Związek Sowieckich Socjalistycznych Republik. 
Inny oficer z NKGB za przyjęcie katolicyzmu i uczęszczanie do kościoła został zwolniony i potem nigdzie odpowiedniej posady nie dostał. Wobec tego trudno mówić o masowym nawróceniu, jednak grunt ku temu się przygotowuje. $\mathrm{W}$ wielu miejscach Rosji, jak słyszałem od osób wiarygodnych, ludność nie ufa swoim duchownym, szczególnie młodszym, wyświęconym po 6-cio miesięcznym kursie w Mińsku, Moskwie itp., uważa ich za agentów NKWD i nie zwraca się do nich po posługi, a raczej do rozmaitych heretyków, których ilość stale się powiększa. Katolicy i ci, którzy słyszeli coś o Kościele katolickim, w dnie świąteczne i niedziele masowo przyjeżdżają do kościołów Zachodniej Białorusi, przystępują do sakramentów św., a prawosławni składają wyznanie wiary. Takie pograniczne parafie, jak Kraśne ${ }^{36}$, Mołodeczno ${ }^{37}$, Raduszkiewicze ${ }^{38}$, Leonpol ${ }^{39}$, Prozoroki ${ }^{40}$, Rakowo $^{41}$ i wiele innych, goszczą u siebie tysiące przybyszów, szukających pociechy religijnej. Parokrotnie u mnie byli delegaci katolików z Leningradu z prośbą, bym się udał do nich na pracę, na co zgodę swą uzależniłem od oficjalnego pozwolenia władz tamtejszych, którego naturalnie nie uzyskałem. Poważnie myślący duchowni prawosławni również widzą jedyną ostoję religijności w katolicyzmie, chętnie się zbliżają do księży katolickich (szczególnie wychowankowie Teologicznego Wydziału Prawosławnego w Warszawie), zapraszają ich na odpustowe obiady i wobec nich rozmawiają tylko po polsku. Byłem w pewnym miejscu na odpuście, gdzie obsługuje kościół proboszcz z sąsiedniej parafii, a w plebani mieści się szkoła powszechna. Ze zdziwieniem dowiedziałem się, że ten proboszcz stale idzie na obiad do popa wobec braku innego miejsca, ja również otrzymałem zaproszenie, z którego nie mogłem skorzystać i wolałem natychmiast wyjechać, ku wielkiemu niezadowoleniu owego popa i proboszcza.

Reasumując wszystko powyższe ośmielam się przedłożyć WASZEJ EMINENCJI swoje następujące wnioski:

a. Wobec braku księży za kordonem, jak i w kraju należałoby zorganizować „Dzieło powołań spóźnionych”, które by ułatwiło przygotowanie do seminarium kandydatów, nie odpowiadających co do wieku latom szkolnym.

b. Należałoby przygotować katechetów i katechetki do prac misyjnych na Wschodzie, jak zresztą i w kraju, jako siły pomocnicze dla kapłanów, których brak jeszcze przez dłuższy okres czasu odczuwać się będzie dotkliwie.

c. W każdej diecezji, a nawet w każdym mieście większym w miarę możliwości należałoby organizować kursa katechetyczne o poziomie wyższym i niż-

${ }^{36}$ Krasne - obecnie miasto na Białorusi, położone nad Uszą, w rejonie mołodeczańskim, w obwodzie mińskim.

${ }^{37}$ Mołodeczno - obecnie miasto na Białorusi, położone nad Uszą, stolica rejonu w obwodzie mińskim.

${ }^{38}$ Radoszkowice - obecnie miasto na Białorusi, w rejonie mołodeczańskim, w obwodzie mińskim.

${ }^{39}$ Lenopol - obecnie wieś na Białorusi, w rejonie mołodeczańskim, w obwodzie mińskim. Przed 1939 r. była to najdalej wysunięta na północ miejscowość należąca do Polski.

${ }^{40}$ Prozoroki - obecnie wieś na Białorusi, w obwodzie witebskim, w rejonie głębockim.

${ }^{41}$ Raków - obecnie miasto na Białorusi, w rejonie wołożyńskim, w obwodzie mińskim. 
szym z przeznaczeniem kandydatów do prac wśród ludu i wśród inteligencji. Można by w tym celu wykorzystać zgromadzenia zakonne.

Przepraszam WASZĄ EMINENCJĘ za śmiałość i pewną chaotyczność w tym raporcie, gdyż brak czasu nie pozwolił mi na systematyczne i dokładne jego opracowanie.

Ze czcią największą całuję świętą purpurę i pozostaję najuniżeńszym i najwdzięczniejszym za wszystko sługą Chrystusa.

/-/ Ks. Michał Sopoćko

Warszawa, 27 VIII 1947 r.

\title{
THE REPORT ABOUT CONDITION OF CATHOLIC CHURCH ON LITHUANIA AND WESTERN BELORUSSIA AFTER SECOND WORLD WAR BY MICHAEL SOPOĆKO
}

\begin{abstract}
Summary
The report about condition of Catholic Church on Lithuania and Western Belorussia from 1947 by Michael Sopoćko tries to fill up the vacancy in the research over position of Church in the USSR after second world war. The description of the persecutions of the Church, prepared by the Vilnius priest, is direct relation by the witness of these events. The report presents important contribution for knowledge of history of Catholic Church on advisable terrains.
\end{abstract}

